\title{
Selection ideatype of a new variety of oil flax adapted to forest-steppe conditions
}

\author{
Zaika Ye. ${ }^{1}$, Drozd O., Kondratyuk V., Pyvovar T. \\ NSC «Institute of Agriculture NAAS» \\ 2b Mashynobudivnykiv Str., Chabany vill., Kyiv-Sviatoshyno district, Kyiv oblast, 08162, Ukraine

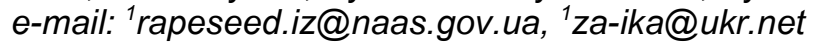 \\ ORCID: 10000-0001-8918-3824
}

\begin{abstract}
Goal. To create a new ideatype of oilseed flax, which will increase seed production in the ForestSteppe with high yields, seed quality, and disease resistance. Methods. Field method - to determine the interaction of the subject of research with natural and agronomic factors; measuring and weighing - to determine the height of plants, yields of straw, fiber, seeds; settlement-comparative - for the economic evaluation of cultivation of different varieties of flax; statistical, dispersion - to identify the reliability of the results of experiments. Results. Based on field researches of the registered modern varieties of oil flax the key economically valuable signs which were used for the creation of a selection ideatype of a variety of oil flax adapted to the Forest-Steppe zone are allocated. Valuable selection lines of oil flax, which have a set of valuable features and significantly exceed the variety standard for productivity, are selected according to the main parameters of the ideatype in the selection process. Conclusions. Based on field researches and data of laboratory analysis the selection ideatype of a variety of oil flax adapted to conditions of the ForestSteppe zone is developed. The proposed model can be used at the preparatory stage of selection - in the selection of parental forms for crossing, and directly in the selection process -in the selection of plants among different generations of hybrids in selection nurseries, and in the assessment of the resistance of varieties to biotic and abiotic factors, which was used in selection work of the NSC "Institute of Agriculture of NAAS".
\end{abstract}

Key words: selection, yield, oil content, lodging.

DOI: https://doi.org/10.31073/agrovisnyk202012-06

Flax (Linum usitatissimum) is a valuable oilseed crop that has long been used by humans. Flax was grown as early as $6-8$ thousand years ago in Egypt and Samaria, and from there it was brought by trade routes to Western Europe in the 5th-3rd millennium BC for the obtaining the expensive oil from seeds[1, 2]. With the mowing to the eastern regions of Europe, flax began to be used more to produce a bast fiber, from which cloth was made [3]. Now the geography of flax cultivation covers almost the entire Earth globe. Canada, China, Ukraine, the Russian Federation and the United States account for $65 \%$ of the world's production of oilseed flax, and the demand for seeds of this crop is growing [1].

Flax oil has valuable nutritional and medicinal properties and has a positive effect on human health (in the prevention of cardiovascular diseases), it is also widely used in the oil paint industry. Flax can be considered the crop of the future since there is high demand flaxseed oil, rich in omega- 3 fatty acids, and flaxseed products containing fiber $[4,5]$. Mucilaginous substances from the surface of flax seeds have been identified as a valuable source of dietary fiber, which can be used to prevent stomach cancer. Therefore, many countries pay great attention to this culture as an indispensable product for Functional Nutrition [6-8]. Flax seeds are also used as an ingredient for bread baking and confectionery [9].

Modern flax varieties differ significantly from wild forms since genotypes with high yield, oil content, and resistance to biotic and abiotic factors were selected during the breeding process [3]. Conscious selection caused changes in the plant morphotype. Fiber flax forms have one long stem that does not branch, while oilseed flax has a much shorter, branched stem. The yield of seeds of oilseed flax varieties in high agriculture conditions is $0.3-0.5 \mathrm{t} / \mathrm{ha}$ higher than that of fiber flax.

With the beginning of synthetic breeding in agricultural production, the importance of the variety as a stable genetic system has increased, which has a complex of biological properties that ensure high yield and product quality under various growing conditions [9]. The intensification of agriculture makes it necessary to grow more agricultural products per unit area, which, accordingly, requires the creation of varieties more adapted to the conditions of the enhanced background of mineral fertilizers, the use of modern protective equipment, and innovative tillage technologies. It is also important to further improve oilseed flax using the latest breeding methods, taking into account the genetic characteristics of the parent components and their subsequent selection based on the ideotype of the variety.

Currently, research is primarily aimed at understanding the variability of agronomically valuable traits and their genetic polymorphism and at identifying the genotype by phenotype. Low breeding productivity is associated with the breeder's lack of a clear understanding of what characteristics should be used to select highly productive genotypes. In the existing selection triad "what to select?"(variety model), "how to 
select?" (breeding theory), and "from what to select?"(polymorphism) it is the first link that has been least studied [11].

To solve this problem, the breeder develops a whole system of traits that have a decisive impact on the productivity potential of a genotype created as a result of several breeding cycles [11]. The concept of a theoretically justified genotype called ideotype or variety model was founded by M. I. Vavilov for grain crops [12]. Even though with the fact that with the development of new scientific areas, such as genomics and bioinformatics, the development of the variety model has changed significantly, the classical concept has remained relevant. The concept of the term "variety model" has two aspects: as a synthesis of existing knowledge about the plant body and its response to changes in environmental conditions, or as a hypothetical ideotype that has an advantage over others [13]. Based on the knowledge of plant biology, the nature of inheritance of individual traits, it is necessary to involve in the breeding process genotypes that most effectively and positively respond to the cultivation technology created by the agronomist [10].

The largest areas under oilseed flax are located in the Steppe zone, where the main limiting factor for its yield is the amount of precipitation during the growing season. The fact that under conditions of sufficient moisture, the potential yield of flax increases is confirmed by research by scientists of the Institute of irrigated agriculture of the National Academy of Agrarian Sciences of Ukraine [14]. Given the trend of recent years to increase the aridity of Steppe regions due to climatic fluctuations [15] and the oversaturation of areas with sunflower and corn, it will be difficult to increase the yield of flax in the Steppe.

The Forest-Steppe zone, especially its central and northern regions, has an optimal water regime, shorter duration, and frequency of periods of strong and insufficient moisture during the growing season of plants, and therefore is favorable for growing oilseed flax. Also, in the conditions of the increasing amplitude of temperature fluctuations, there is a need to create new varieties of flax with high potential productivity.

Currently, domestic researchers from the Institute of Oil Crops of the National Academy of Agrarian Sciences have developed a parametric model of the oilseed flax variety for the steppe zone, which includes the researching of a significant amount of initial material, but such studies on flax breeding have not yet been conducted for the Forest-Steppe zone. Therefore, the creation of a new ideotype of the variety for the Forest-Steppe zone is no less an actual task [16].

The aim of the work was to develop an ideotype of oilseed flax variety adapted to Forest-Steppe conditions to accelerate breeding work, plan new breeding strategies, and create clear criteria for the breeding work.

Conditions and methods of conducting researches. The research was conducted during 2016-2019 in the conditions of breeding crop rotation in the village of Chabany of the Kyiv-Svyatoshinsky District of the Kyiv region. The climate of the Forest-Steppe zone of Ukraine is moderately continental.

The soil is middle sod-podzolic powdery sandy loam, the depth of the arable layer is $20-22 \mathrm{~cm}$, the humus content is $1-1.6 \%$, the $\mathrm{pH}$ of the salt solution is $5.4-6.0$, the hydrolytic acidity is $2.1-2.4 \mathrm{mg}-\mathrm{EQ}$. per $100 \mathrm{~g}$ of soil, the degree of saturation with bases is $55.3-58.0 \%$. The content of nutrients in the soil is within the following limits: easily hydrolyzed nitrogen $-5.5-7.0 \mathrm{mg}$ per $100 \mathrm{~g}$ of soil; mobile phosphorus 12.3-13.6 mg per $100 \mathrm{~g}$ of soil; exchange potassium - 7.0-8.4 mg per $100 \mathrm{~g}$ of soil. So, the soil is slightly acidic, that is, suitable for growing oilseed flax. At the same time, the supply of soil with basic nutrients is sufficient. The predecessor of agro technical experiments in crop rotation was grain crops.

We studied the varieties: Evrika, Blakytno-Pomarachevyi, Oryginal, Sympatyk, which are included in the Register of plant varieties allowed for use in Ukraine, and 8 breeding lines of the nursery of competitive variety testing, according to the parameters of the yield structure, biochemical characteristics, height, lodging, and diseases resistance (table.1). The assessment of varieties was carried out according to the method of State Variety testing $[17,18]$. The standard was the variety Pivdenna Nich. The oil content and protein content were determined by infrared spectroscopy on an Infratec (FOSS), the content of fatty acids was detected on an Agilent 7820 gas chromatograph (Alsi-Chrom). Statistical data processing was carried out using the Microsoft Office software package according to the method of B. A. Dospekhov [19].

Results of researches. Based on the obtained yield data of the best varieties of Ukrainian breeding, we create a model of the variety with a given genetic productivity potential for specific soil and climatic conditions. According to the results of field studies, the varieties of the NSC "Institute of Agriculture of the National Academy of Sciences" were characterized by the main economically valuable characteristics. Among the studied set of varieties, key indicators were identified for characteristics that directly affect yield and adaptability, based on which the ideotype of the variety for the Forest-Steppe zone is constructed (table 1). 
1. Conditional ideotype of the oilseed flax variety for the forest-steppe zone, 2016 - 2018

\begin{tabular}{|c|c|c|c|c|c|}
\hline \multirow[b]{2}{*}{ Traits } & \multicolumn{4}{|c|}{ Variety } & \multirow[b]{2}{*}{$\begin{array}{c}\text { Suggested } \\
\text { parameters } \\
\text { of } \\
\text { model }\end{array}$} \\
\hline & Evrika & $\begin{array}{l}\text { Blakytno- } \\
\text { Pomaranchevyi }\end{array}$ & Sympatyk & Oryginal & \\
\hline $\begin{array}{l}\text { Duration of vegetation } \\
\text { period, days }\end{array}$ & 85.0 & 93.0 & 85.0 & 82,0 & 80,0 \\
\hline Productivity, t/ha & 2.50 & 2.13 & 2.00 & 2.15 & 2.70 \\
\hline \multicolumn{6}{|c|}{ Seed quality parameters } \\
\hline Oil content, \% & 44.19 & 48.64 & 38.16 & 45.28 & 48.00 \\
\hline Protein, $\%$ & 23.40 & 22.8 & 23.16 & 24.23 & 25.80 \\
\hline Oleic acid content, $\%$ & 18.96 & 18.55 & 17.35 & 17.47 & 20.00 \\
\hline Linoleic acid content, \% & 13.95 & 13.53 & 14.63 & 16.82 & 15.00 \\
\hline Linolenic acid content, \% & 55.99 & 58.09 & 56.54 & 56.98 & 60.00 \\
\hline \multicolumn{6}{|c|}{ Elements of the yield structure } \\
\hline Number of pods, pcs & 17.40 & 18.80 & 14.20 & 17.25 & 19.00 \\
\hline Seeds per pod, pcs & 9.00 & 8.00 & 7.00 & 8.00 & 9.00 \\
\hline $\begin{array}{l}\text { Number of seeds per } \\
\text { plant, pcs }\end{array}$ & 135.00 & 138.00 & 149.00 & 152.00 & 160.00 \\
\hline $\begin{array}{l}\text { Weight of seeds per } \\
\text { plant, mg }\end{array}$ & 923.30 & 728.00 & 562.40 & 581.15 & 963.00 \\
\hline Weight of 1000 seeds, $\Gamma$ & 9.43 & 7.60 & 5.83 & 5.86 & 9.70 \\
\hline \multicolumn{6}{|c|}{ Resistance to biotic and abiotic factors } \\
\hline Plant height, $\mathrm{cm}$ & 35.8 & 43.4 & 46.4 & 44.1 & 45.0 \\
\hline $\begin{array}{ll}\text { Lodging } & \text { resistance, } \\
\text { points } & \\
\end{array}$ & 9 & 9 & 8 & 9 & 9 \\
\hline $\begin{array}{l}\text { Resistance against a } \\
\text { complex of diseases, } \\
\text { points }\end{array}$ & 9 & 8 & 8 & 8 & 9 \\
\hline \multicolumn{6}{|c|}{ Marker phenotypic features } \\
\hline Flower color & $\mathrm{BL}$ & W & $P$ & W & $\mathrm{BL} / \mathrm{W}$ \\
\hline Seed color & B & $\mathrm{Y}$ & $\mathrm{Y}$ & $\mathrm{O}$ & $\mathrm{B} / \mathrm{Y}$ \\
\hline
\end{tabular}

Notes. $\mathrm{BL}$ - blue, $\mathrm{W}$ - white, $\mathrm{B}$ - brown, $\mathrm{Y}$ - yellow, $\mathrm{P}$ - pink, $\mathrm{O}$ - olive.

Elements of the ideotype of the variety are conventionally divided into four areas of improvement: seed quality indicators, elements of the yield structure, resistance to biotic and abiotic factors, and marker phenotypic features (table 1). The yield and duration of the growing season were not assigned to any of the groups, since these are complex traits due to complex gene interactions.

One of the most important characteristics of flax is the length of the growing season, which affects the realization of the productivity potential inherent in the genotype of the variety [20]. Most varieties suitable for distribution in Ukraine are precocious and have a growing season duration of 80-90 days. Early genotypes make better water reserves in the initial stages of development, and therefore early maturation is likely to have an advantage in drought conditions as well. Also, an early-maturing variety is an optimal precursor in crop rotation, since it frees up the field for the next crop faster.

Yield is a complex trait due to many factors [21,22]. Modern varieties of flax have potential productivity of $2.0-2.5 \mathrm{t} / \mathrm{ha}$, but in production, it is sold only at best at the level of $1.0-1.5 \mathrm{t} / \mathrm{ha}$. Therefore, a future increase in the yield of oilseed flax is likely to be possible through the selective improvement of genotypes based on yield structure and adaptability. The studied varieties have a yield of 2.0-2.15 t/ha. Among the analyzed samples, the Evrika variety was distinguished, which had an average yield of $2.5 \mathrm{t} / \mathrm{ha}$. This is not enough to ensure a high economic effect from growing flax, so the model of the variety includes a yield of $3.0 \mathrm{t} / \mathrm{ha}$.

Such biochemical parameters as oil content and protein content are important for processors, while the fatty acid composition of oil affects the direction of the use of seeds of a particular variety [23]. Oil content is a trait controlled by a complex of genes and depends on many external factors - temperature conditions, 
photosynthetically active radiation, soil fertility, water supply, etc. [22, 24]. Studies by individual authors have established that grain size and color also affected oil content. The authors associate higher oil content with the yellow color of the seed coat [25]. However, the determining factor affecting the "oil content" attribute is the genetic characteristics of the variety. Among the varieties analyzed by us, the highest oil content was found in the variety Blakytno-Pamaranchevyi, which is characterized by yellow (golden) seed color (48.64\%). Most of the studied varieties had oil content of $38-44 \%$, so in the model of the variety, we put this parameter $2 \%$ higher, which in the future will make it possible to increase the yield of oil per unit area.

In addition to the oil content, its fatty acid composition is very important. Flax is widely known as a source of polyunsaturated fatty acids [26]. These acids belong to the group of essential acids, and therefore have a high nutritional and therapeutic value. Flaxseed oil also contains valuable oleic acid monounsaturated fatty acid, which also has a positive effect on the nutritional properties of seeds and products. With this in mind, the increased content of linoleic, linolenic, and oleic fatty acids was introduced into the model of the oilseed flax variety for universal use as an important biochemical characteristic of seeds. As a result of the gas chromatographic analysis, as well as the content of such polyunsaturated acids as linoleic acid and linolenic acid, the highest indicator was in the variety Blakytno-Pamaranchevyi $(13.53 \%$ and $58.09 \%$, respectively). The highest content of oleic acid was found in the variety Evrika $(18.96 \%)$.

Signs of the yield structure are the main in the formation of the yield of oilseed flax since they are its direct components. According to the characteristics of the yield structure, the Evrika variety is the leader, since it has a high manifestation in terms of the "number of balls per plant" (17.40 pcs.), "the number of seeds of a box" (9.0 pcs.), "number of seeds per plant" (135 pcs.), "weight 1000 seeds" (9.43 g) and "weight of seeds from a plant" $(583.0 \mathrm{mg})$. In our opinion, selection by weight of 1000 seeds with simultaneous rejection of genotypes with a low average seed weight from the plant has prospects.

Polyakova I. A. et al. (2005) consider marker phenotypic features important for the breeding model of a variety, which on the one hand facilitate seed production, and on the other - the identification of a particular variety [16]. Therefore, such signs as a flower corolla color and seed color are included in a separate group of phenotypic marker features. You can also use the anther color attribute and others.

The conditional ideotype also includes complex disease resistance, which is necessary to guarantee high and stable yields over the years. The "plant height" attribute is important in conditions with unstable weather conditions and wind blowing, as it influences lodging resistance. Most varieties had a similar average plant height $(42 \mathrm{~cm})$ and resistance to lodging at the level $(8-9$ points). Therefore, as a basis for the ideotype, we took the average height close to the already zoned varieties.

Based on some parameters of the breeding ideotype of oilseed flax, the Department of Breeding and Seed Production of Flax and Rapeseed of the National Research Center "Institute of Agriculture of the National Academy of Agrarian Sciences of Ukraine" has created a source material that can be used in the breeding process. The characteristics of the obtained breeding lines are shown in Table 2. As can be seen from Table 2, the yield of new lines ranged from 2.19 to $2.89 \mathrm{t} / \mathrm{ha}$, which is close to or exceeds the specified ideal type of variety. In terms of yield, were distinguished lines - 1-16 (2.60 t/ha), 4-16 (2.64 t/ha), 7-16 (2.85 t/ha), 8-16 (2.89 t/ha).

2. Characteristics of the best breeding lines of oilseed flax and its elements in competitive variety testing, 2016-2018

\begin{tabular}{|c|c|c|c|c|c|c|}
\hline $\begin{array}{c}\text { Name of } \\
\text { sample }\end{array}$ & $\begin{array}{c}\text { Seed } \\
\text { productiv } \\
\text { ity, t/ha }\end{array}$ & $\begin{array}{c}\text { A number } \\
\text { of pods } \\
\text { per plant, } \\
\text { pcs. }\end{array}$ & $\begin{array}{c}\text { A number } \\
\text { of seeds } \\
\text { per pod, } \\
\text { pcs. }\end{array}$ & $\begin{array}{c}\text { A number } \\
\text { of seeds } \\
\text { per plant, } \\
\text { pcs. }\end{array}$ & $\begin{array}{c}\text { Weight of } \\
\text { seeds of } \\
\text { the plant, } \\
\text { mg }\end{array}$ & $\begin{array}{c}\text { Weight of } \\
\mathbf{1 0 0 0} \text { seeds, } \\
\mathbf{g}\end{array}$ \\
\hline $\begin{array}{c}\text { Pivdenna } \\
\text { Nich (St) }\end{array}$ & 2.15 & 15.30 & 8 & 122 & 946 & 8.0 \\
\hline $\mathbf{1 - 1 6}$ & $\mathbf{2 . 6 0}$ & 16.24 & 9 & 149 & 1097 & 8.3 \\
\hline $\mathbf{2 - 1 6}$ & 2.23 & 15.40 & 8 & 132 & 1042 & 8.9 \\
\hline $\mathbf{3 - 1 6}$ & 2.20 & 16.82 & 7 & 120 & 856 & 7.4 \\
\hline $\mathbf{4 - 1 6}$ & $\mathbf{2 . 6 4}$ & 19.34 & 8 & 158 & 1234 & 8.5 \\
\hline $\mathbf{5 - 1 6}$ & 2.53 & 16.28 & 8 & 135 & 1292 & 9.2 \\
\hline $\mathbf{6 - 1 6}$ & 2.44 & 15.23 & 9 & 138 & 1178 & 9.0 \\
\hline $\mathbf{7 - 1 6}$ & $\mathbf{2 . 8 5}$ & 20.48 & 9 & 198 & 1451 & 9.6 \\
\hline $\mathbf{8 - 1 6}$ & $\mathbf{2 . 8 9}$ & 19.75 & 10 & 199 & 1343 & 9.7 \\
\hline$\overline{\mathbf{X}}$ & 2.61 & 17.61 & 9 & 160 & 1193 & 8.7 \\
\hline $\mathbf{L S D}_{\mathbf{0 5}}$ & 0.4 & - & - & - & - & - \\
\hline Min & 2.19 & 15.23 & 8 & 138 & 984 & 7.95 \\
\hline Max & $\mathbf{2 . 8 9}$ & 20.48 & 9 & 203 & 1831 & 9.91 \\
\hline
\end{tabular}


The same samples differed in the elements of the yield structure: the number of pods per plant, the number of seeds in the pod, the number of seeds per plant, the mass of seeds per plant, and the mass of 1000 seeds. In terms of the number of boxes on the plant, the samples were close to the developed model of the variety, while in terms of the mass of seeds from the plant, it prevailed.

We also studied the biochemical characteristics of flax, such as oil content, the fatty acid content in oil, protein content, as well as resistance to lodging, and Fusarium (table 3).

In terms of oil content, the samples were at the level of the Pivdenna Nich standard variety. On average, the oil content in the sample of varieties was $46 \%$. The samples were distinguished by the highest oil content 1-16 (48\%), 4-16 (48\%), 5-16 (48\%).

The average content of oleic acid in variety samples was $17.41 \%$, and it was highest in samples $6-16$ (19\%), and 3-16 (18\%). Samples 1-16(18\%) and 5-16(15\%) were distinguished by the content of linoleic acid. Samples of oilseed flax were characterized by a high content of linolenic acid: from 55 to $61 \%$, of which variety samples had the highest indicators 4-16 (61\%), 1-16 (58,14\%) and 3-16 (57\%).

\section{Characteristics of the best breeding lines of oilseed flax by biochemical parameters and resistance to certain biotic and abiotic factors in competitive variety testing, 2016-2018}

\begin{tabular}{|c|c|c|c|c|c|c|c|}
\hline $\begin{array}{c}\text { Name of } \\
\text { sample }\end{array}$ & $\begin{array}{c}\text { Oil } \\
\text { conte } \\
\text { nt, \% }\end{array}$ & $\mathbf{1 8 : 1}$ & $\mathbf{1 8 : 2}$ & $\mathbf{1 8 : 3}$ & $\begin{array}{c}\text { Protein } \\
\text { content } \\
\mathbf{\%}\end{array}$ & $\begin{array}{c}\text { Lodging } \\
\text { resistance, } \\
\text { points }\end{array}$ & $\begin{array}{c}\text { Fusarium } \\
\text { resistance, } \\
\text { points }\end{array}$ \\
\hline $\begin{array}{c}\text { Pivdenna } \\
\text { Nich (St) }\end{array}$ & 42.28 & 17.85 & 12.95 & 56.15 & 24.5 & 4.3 & 4.0 \\
\hline $\mathbf{1 - 1 6}$ & 48.12 & 17.38 & 17.96 & 58.14 & 24.2 & 5.0 & 5.0 \\
\hline $\mathbf{2 - 1 6}$ & 44.82 & 16.74 & 12.68 & 56.54 & 25.3 & 5.0 & 5.0 \\
\hline $\mathbf{3 - 1 6}$ & 46.44 & 18.23 & 12.94 & 57.18 & 24.8 & 5.0 & 4.0 \\
\hline $\mathbf{4 - 1 6}$ & 47.69 & 17.14 & 13.75 & 61.13 & 23.8 & 5.0 & 5.0 \\
\hline $\mathbf{5 - 1 6}$ & 47.75 & 17.54 & 15.21 & 58.11 & 24.9 & 4.7 & 4.5 \\
\hline $\mathbf{6 - 1 6}$ & 46.55 & 18.98 & 13.56 & 54.68 & 24.7 & 5.0 & 5.0 \\
\hline $\mathbf{7 - 1 6}$ & 47.12 & 15.39 & 13.48 & 57.64 & 22.8 & 5.0 & 5.0 \\
\hline $\mathbf{8 - 1 6}$ & 47.35 & 15.39 & 13.48 & 57.64 & 22.8 & 5.0 & 5.0 \\
\hline$\overline{\mathbf{x}}$ & 46.35 & 17.41 & 14.07 & 57.82 & 24.38 & - & - \\
\hline Min & 45 & 15.39 & 12.68 & 54.68 & 22.80 & 4.30 & 4.00 \\
\hline Max & 43 & 18.98 & 17.96 & 61.13 & 25.30 & 5.00 & 5.00 \\
\hline
\end{tabular}

Notes. 18:1 - oleic acid; 18:2 - linoleic acid; 18:3 - linolenic acid.

The protein content of the samples ranged from $22.8 \%$ to $25.0 \%$. The highest protein content was found in breeding lines 3-16 and 5-16 (25\%).

Resistance to lodging is important in years with severe thunderstorms accompanied by wind gusts. Oilseed flax is more resistant to lodging compared to fiber flax, but in some years due to lodging, there are significant crop losses, because harvesting such crops by a combine is difficult, and the crops themselves are intensively damaged by various types of fungi of the genus Fusarium, which cause seed infections and a sharp decrease in the quality of seed material. Therefore, resistance to lodging and Fusarium damage are important features that are included in the model of the oilseed flax variety developed by us. In the study of lodging resistance, most of the samples were stable at the level of 5 points. Individual samples were distinguished by their resistance to Fusarium infection (5 points) - 1-16, 2-16, 4-16, 6-16, 8-16.

\section{Conclusions}

Based on field studies and laboratory analysis data, a breeding ideotype of the oilseed flax variety adapted to the conditions of the Forest-Steppe zone of Ukraine has been developed. The proposed model can be used at the preparatory stage of breeding - when selecting parent forms for crossing, and directly in the breeding process - when selecting plants among different generations of hybrids in breeding nurseries, and when assessing the resistance of varieties to biotic and abiotic factors. At this stage, the formation of the ideotype cannot be considered complete and the list of necessary characteristics should be updated taking into account the latest achievements in breeding and applied genetics of oilseed flax. Based on the developed variety model, the National Research Center "Institute of Agriculture of the National Academy of Agrarian Sciences of Ukraine" selected breeding lines that predominate or are close to the selected criteria and can be used in the future to create new genotypes with a high manifestation of economically valuable traits. Research on the biological basis of crop productivity, in particular flax, is of great relevance due to the need for accelerated creation of varieties and variety substitution, increased competition in the domestic seed market by foreign companies, and increasing production requirements for new varieties. 


\section{References}

1. Zohary, D., \& Hopf, M. (2000). Domestication of plants in the Old World: the origin and spread of cultivated plants in West Asia, Europe and the Nile Valley. Oxford University Press, Oxford.

2. Dewilde, B. (1983). 20 eeuwen vlas in Vlaanderen.

3. Gill, K.S. (1987). Linseed. Indian Council of Agricultural Research. New Dehli.

4. Kaur, V., Yadav, R., \& Wankhede, D.P. (2017). Linseed (Linum usitatissimum L.) genetic resources for climate change intervention and its future breeding. Journal of Applied and Natural Science, 9 (2), $1112-1118$.

5. Nag, S., Mitra, J., \& Karmakar, P.G. (2015). An overview on flax (Linum usitatissimum L.) and its genetic diversity. Int J Agric Environ Biotechnol, 8, 805-8017. doi: 10.5958/2230-732X.2015.00089.3

6. Boclé, J.C., Champ, M., \& Berta, J.L. (2005). Les fibres alimentaires: denerminants physicochimiques, definition, aspects analitiques et physiologiques. Can. Nutr. Diet, 40(1), 15-21.

7. NACRe. Fibres et prévention du cancer colorectal. (2001). Let. Sc. IFN, 81, 1-12.

8. Tarpila, A., Wennberg, T., \& Tarpila, S. (2005). Flaxseed as a functional food . Current Topics in Nutraceutical Research, 3(3), 167-188.

9. Rowland, G.G. (1998). Growing flax: Production, management and diagnostic guide. Flax Council of Canada and Saskatchewan Flax Development Commission.

10. Orluk, A.P., \& Korchynskiy, A.A. (1989). Fizioloho-henetychna model sortu ozymoi pshenytsi [Physiology and genetical model of winter wheat variety]. Kyiv: Holovne vydavnytstvo (in Ukrainian).

11. Koval, S.F., Koval, V.S., \& Chernakova, V.M. (2005). Chto takoe model sorta? [What is it the variety model]. Omsk (in Russian).

12. Vavilov, N. I. (1967). Izbrannyie proizvedenia [Selected works]. In 2 vol.V. 2. Nauka (in Russian).

13. Starzycki, S. (1980). Biological basis of modeling cultivars / Well-being of mankind and genetics . Mir publishers, 1 (2).

14. Vozhegova, R., Borovik, V., \& Konovalova, V. (2020). Urozhainist i yakist nasinnia sortiv lonu oliinoho v Pivdennomu Stepu Ukrainy zalezhno vid riznykh umov vyroshchuvannia [Yield and quality of seeds of oilseed flax varieties in the Southern Steppe of Ukraine depending on different growing conditions]. Bulletin of Agrarian Science, 98(3), 82-87. doi: 10.31073/agrovisnyk202003-12 (in Ukrainian).

15. Kucher, A.V. (2019). Strategichni naprjami rozvitku nizkovuglecevogo zemlekoristuvannja jak zaporuki stijkosti do zmin klimatu: monography [Strategic directions for the development of low-carbon land use as a key to climate change resilience]. Kharkiv: FOP Brovin O.B., doi: 10.13140/RG.2.2.22016.38400 (in Ukrainian).

16. Poliakova, I. A. (2015). Model sorta Ina maslychnoho dlia Stepnoi zoni [Model of the oilseed flax variety for the Steppe zone]. Scientific and technical Bul. IOK NAAS, 22, 26-34.

17. Lyakh, V. A., \& Polyakova, I. A. (2008). Selektsiia lonu oliinoho: metod. rekom [Breeding of oilseed flax: methodical recommendation]. Zaporizhdzhia, (in Ukrainian).

18. Andruschenko, A.V., \& Pilkevych, A.V. (2001). Sortovyprobuvannia priadyvnykh kultur. Metodyka derzhavnoho sortovyprobuvannia silskohospodarskykh kultur: oliini, tekhnichni, priadyvni ta kormovi kultury [Variety testing of hemp crops. Methodology of State Variety testing of agricultural crops: oilseeds, technical, hemp and fodder crops]. Kyiv: Alefa, 44-50 (in Ukrainian).

19. Dospekhov, B.A. (1985). Metodyka polevoho opyta [Methodic of field experiment]. Moscow: Ahropromizdat. (in Russian).

20. Diakov, A.B. (2006). Fyzyolohyia i ekolohyia Ina [Physiology and Ecology of Flax]. Krasnodar, (in Russian).

21. Zajac, T., Oleksy, A., Klimek-Kopyra, A., \& Kulig, B. (2012). Biological determinants of plant and crop productivity of flax (Linum usitatissimum L.). Acta Agrobotanica, 65 (4), 3-14. doi: doi: 10.5586/aa.2012.016

22. Poliacova, I. A., Ruchka, V. A., \& Nikitenko, O. V. (2005). Vlyianye uslovyi vyrashchyvanyia na produktyvnost Ina maslychnoho [Influence of growing conditions on the productivity of oilseed flax]. Science technical Bul. Institute of oilseeds of the UAAS, 10, 179-183 (in Russian).

23. Brach, N.B., \& Prokhorova, Ye.A. (2005). Nasledovanye morfolohycheskykh i khoziaistvennotsennykh pryznakov u Ina (Linum usitatissimum). Ydentyfytsyrovannyi henofond rastenyi y selektsyia. [Inheritance of morphological and economically valuable traits in flax (Linum usitatissimum). Identified the gene pool of plants and breeding]. Saint-Petersburg, 303-327 (in Russian).

24. Vereshchagin, A. G. (1976). Vlyianye fenotypa y henotypa maslychnykh rastenyi na zhyrnokyslotnyi sostav masla [Influence of the phenotype and genotype of oilseeds on the fatty acid composition of oil]. Plant physiology, 23(3), 600-613 (in Russian).

25. Popescu, F., Marinescu, I., \& Vasile, I. (1981). Combining ability and heredity of some important traits in linseed breeding. Australian Journal of Agricultural Research, 32(4), 599 - 607.

26. Morris, D. H. (2007). Flax - A Health and Nutrition Primer. 4th ed., Ithaca, NY, Flax Council of Canada. 